\title{
Tense and Aspect Markers of Cirebon Javanese
}

\author{
Leny Saili Rahmah \\ English Education Department \\ Universitas Islam Nusantara \\ Bandung, Indonesia \\ lenysailiR@gmail.com
}

\author{
Eri Kurniawan \\ English Education Department \\ Universitas Pendidikan Indonesia \\ Bandung, Indonesia \\ eri_kurniawan@upi.edu
}

\begin{abstract}
This paper examines tense and aspects markers in the Javanese dialect of Cirebon. This language is included Western Malayo-Polynesian, Austronesian, spoken in West Java, Indonesia. Varieties of Javanese display a wide range of variation not only in lexicon and pronunciation but also in various aspects markers. This paper identifies three aspect markers in Cirebon Javanese: wis, lagi, and arep. Aspect marker wis expresses Perfect Aspect and comes before Verb. Wis comes before Adjective. Besides, Wis cannot be a past tense or a perfective aspect marker. Lagi expresses Progressive and Past-Progressive. It cannot be a progressive aspect marker. Arep expresses Future, with differences between arep expressing will or be going to, and arep that expresses wish. Cirebon Javanese has a different vocabulary from other Javanese dialects. However, for aspect markers, Cirebon Javanese's aspect markers are similar to standard Javanese's aspect markers.
\end{abstract}

\section{Keywords: aspect markers, Cirebon Javanese, typology}

\section{INTRODUCTION}

Javanese is region language in Indonesia. Over 90 million people speaks Javanese. A well-known property of Javanese is its speech levels: ngoko 'Low Javanese', madya 'Mid Javanese', and krama 'High Javanese' (for example, Errington 1985, 1988). There are standard Javanese and non-standard Javanese. Standard Javanese is from Yogyakarta (Yogya) and Surakarta (Solo) (e.g Suharno, 1982). Varieties of Javanese display a wide range of variation not only in lexicon and pronunciation, but also various aspects markers. The present study examines aspect markers in the variety of Javanese spoken in the region of Cirebon, covering roughly the city and kabupaten (county) of the same name. Cirebon is situated on the north coast of the province of West Java, and forms a linguistic border with the Sundanese speaking area to the west. While sometimes popularly characterized as a mixed language, Cirebon Javanese is a variety of Javanese. However, it is one that exhibits some influences from Sundanese and Malay, some archaisms no longer used in many other varieties of Javanese, as well as its innovations. These characteristics make it quite distinct from the variety associated with the court cities of Yogyakarta and Surakarta, which are often taken to be the standard form of the language (Ewing, 2014). In addition, the same as other languages, Javanese has tenses. However, different from English tenses, Javanese tenses can be marked by aspect marker.

Aspect marker related to the internal situation. According to (Comrie, 1976, p.265), "Aspect is not concerned with relating the time of the situation to any other time-point, but rather with the internal temporal constituency of the one situation".

Javanese verbs are not marked for person or number and there is only little morphosyntactic marking for TAMcategories. TAM-categories in Javanese are marked by auxiliary words, occurring in pre-verbal position (Robson, 1992, p.64). In Cirebon Javanese sentence, verbs in Javanese are unmarked for either tense or agreement, the aspect markers may be manifested in the system of temporal auxiliaries. Aspect markers may occur before the Verb Phrase (VP). These aspects are sometimes referred to as tenses in English descriptions of Javanese. There are three aspect markers in Cirebon Javanese. They are: wis 'Perfective', lagi 'Durative', arep 'Future'. Vander Klok (2008), argues that while Javanese auxiliaries share some properties with verbs, they should be considered a separate category on the basis of their different morphosyntactic behavior. Javanese also has a number of markers with aspectual meanings that help disambiguate the temporal reference of predicates, such as tau 'EXP.PRF' or lagi 'PROG' (Standard Javanese; Robson, 2002) /(la)gek 'PROG, just' (Paciran Javanese; Vander Klok 2012).

Javanese wis has also been glossed as a perfective in many theses (Vander Klok, 2012) and defined as a past tense marker (in the second entry in Robson \& Wibisono's dictionary). Lagi is mentioned by Uhlenbeck (1975) and Sawardi (2004) by the meaning of 'in the middle of processes. However, it is more similar to present continuous tense in English. The marker ape or pe in Paciran Javanese, (or arep in Cirebon Javanese) expresses future and can occur with weather predicates (Vander Klok, 2012). These markers are summarized in Table I.

TABLE I. GLOSSES OF ASPECT MARKERS IN CIREBON JAVANESE

\begin{tabular}{|l|l|l|}
\hline No & \multicolumn{1}{|c|}{ Aspect Markers } & \multicolumn{1}{c|}{ Gloss } \\
\hline 1 & Wis & Pref 'already' \\
\hline 2 & Lagi & Prog 'just' \\
\hline 3 & Arep & Fut \\
\hline
\end{tabular}

Javanese has some varieties that display a wide range of variation not only in lexicon and pronunciation but also in various aspects markers. Four Javanese dialects have been analyzed; they are Tangger Javanese, Peranakan Javanese, Tegal Javanese, and standard Javanese. The differences of Javanese aspect markers among Tangger Javanese, Peranakan Javanese, Tegal Javanese, standard Javanese and Cirebon Javanese showed in Table II. 
TABLE II. ASPECT MARKERS LIST ACROSS FOUR DIALECTS IN JAVANESE

\begin{tabular}{|l|l|l|l|l|l|l|}
\hline $\begin{array}{l}\text { 'Standard Javanese' } \\
\text { (Horne 1961, Dahl } \\
\begin{array}{l}\text { 1985, Robson 1992, } \\
\text { R\&W 2002, Vander } \\
\text { Klok 2012) }\end{array}\end{array}$ & $\begin{array}{l}\text { Tengger Javanese } \\
\text { (Conners 2008) }\end{array}$ & $\begin{array}{l}\text { Peranakan Javanese } \\
\text { (Cole, Hara, \& Yap } \\
\text { 2008) }\end{array}$ & $\begin{array}{l}\text { Tegal Javanese } \\
\text { (Suwadji 1981) }\end{array}$ & $\begin{array}{l}\text { Paciran Javanese } \\
\text { (Vander Cirebon Javanese } \\
\text { Klok }\end{array}$ & Core gloss \\
\hline Lagi & Gek & Gek & Lage, lagi & Lagek, gek & Lagi & \\
\hline Wis & Wis & Wis & Wis, ewis & Wis, uwis & Wis & PROG \\
\hline Arep & Kate & Meh & Ape & Ape & Arep & PERF \\
\hline
\end{tabular}

It is clear that while some aspect markers are similar across dialects, others have different forms. This similarity is in contrast to the many forms of the future marker across dialects such as bakal, kate, meh, ape or arep; it is currently not known if these different phonological forms also differ semantically or syntactically from each other.

\section{FINDINGS AND DISCUSSION}

A. Aspect Marker wis

TABLE III. THE MARKER WIS ACROSS A NUMBER OF JAVANESE DIALECTS

\begin{tabular}{|l|l|l|}
\hline \multicolumn{1}{|c|}{ Form } & \multicolumn{1}{|c|}{ Dialect } & \multicolumn{1}{c|}{ References } \\
\hline Wis & Cirebon, West Javanese & Ewing (2005) \\
\hline Wis & Tegal, Central Javanese & Suwadji (1981) \\
\hline Wis & Semarang, Central Javanese & $\begin{array}{l}\text { Goebel (2002, } \\
\text { 2005,2010) }\end{array}$ \\
\hline Wés, wis & $\begin{array}{l}\text { Yogyakarta, Central } \\
\text { Javanese } \\
\text { Solo, Central Javanese } \\
\text { (Standard Javanese) }\end{array}$ & $\begin{array}{l}\text { Favre (1866); Home } \\
(1961) ; \text { Robson } \\
\text { (2002); Robson \& } \\
\text { Wibisono (2002); } \\
\text { Wedhawati et al. } \\
(2006)\end{array}$ \\
\hline Wis & $\begin{array}{l}\text { Paranakan; Semarang, } \\
\text { Central Java }\end{array}$ & Cole et al. (2008) \\
\hline Wis & Tengger, East Javanese & Conners (2008) \\
\hline Wis & Surabaya, East Javanese & Hoogervorst (2010) \\
\hline Wes, wis & Paciran, East Javanese & Vander Klok (2012) \\
\hline \multicolumn{2}{|c|}{ Adopted from Vander klok (2015) } \\
\hline
\end{tabular}

Aspect marker wis for example is consider a marker of tense rather than aspect in Vander Klok (2012). Comrie (1976, p. 272) considers this presenrelevance of the past situation one of the defining characteristic of perfect aspect. Aspect marker wis may occur before the verb phrase (VP). Aspect marker wis that has description as perfective has analyzed by researchers in variaty Javanese. There are 8 researches that have analyzed it, they are Cirebon Javanese dialect, Tegal Javanese dialect, Semarang Javanese dialect, standard Javanese, Paranakan Javanese dialect, Tengger Javanese dialect, Surabaya Javanese dialect, Paciran Javanese dialect. The Marker wis across a number of javanese dialects showed in Table III above.

1) Wis Expresses Perfect Aspect and come before Verb

Aspect marker wis has description perfective in English Tenses. Dahl (1985) reports that, based on his questionnaire, the marker wis expresses perfect aspect because it occurs in all of his prototypical example for the perfect. Dahl does not report which dialect of Javanese is researched for the questionnaire. Dahl (1985, p.39) also notes that the questionnaire was only completed by one consultant for most languages, which likely includes Javanese. Here are the examples of wis expresses perfect marker:

\section{CIREBON JAVANESE}

(1) Nanang wis tuku sega kuning mau Nanang PRF AV-buy rice yellow just now 'Nanang has bought yellow rice just now.'

(2) Wis adus durung sira? PRF AV-take a shower not yet you 'Have you taken a shower?'.

(3) Bapae wis teka sing Bogor Father-DET PRF AV-come from Bogor 'Her father has arrived from Bogor'.

In (1) wis indicates perfect tense (recent past), 'tuku' done not long before the speech, beside that in this sentence there is the adverb of time 'mau' to make clear the time. While (2) wis indicates perfect tense (question word and result), it shows the result of 'adus'. There is question here because to know the result from 'adus' as a verb. 'adus durung sira' as verb phrase. Then in (3) wis come before verb phrase 'teka'. 'teka sing Bogor' is verb phrase after wis. It indicates perfect tense (recent past).

\section{2) Wis Come before Adjective}

Aspect marker wis can occur come before adjective. It can be seen from the example in (4). no differentiation the position of wis. Wis comes before verb phrase or before adjective phrase.

\section{CIREBON JAVANESE}

(4) Sira wis sue ora mene-mene You PRF long time didn't come here 'You have been long time didn't come here."

3) Wis can not be a past tense or a perfective aspect marker

In some situation wis can not be a past tense or perfective aspect marker

\section{CIREBON JAVANESE}

(5) Mang Jojo wis waras Uncle Jojo PROG well 'Uncle Jojo is well.' 
The position of Wis in (5) is as a progressive. It can be translated uncle Jojo is well. The auxiliary wis in Javanese cannot be a perfective marker, as glossed in Conners (2008), Hoogervorst (2010), and Vander Klok (2012). Languages that have perfective aspect also have a contrasting imperfective. However, some languages only overtly mark one of these aspects; across languages, there is no "marked/ unmarked" distinction between the perfective/imperfective aspect (for example, Dahl, 1985; Dahl \& Velupillai, 2013).

\section{B. Aspect marker lagi}

Vander Klok (2012) argued that the aspectual marker lagek or gek can express progressive aspect or inceptive aspect (focusing on the beginning of the event). Two examples are given in (37)-(38):

\section{PACIRAN JAVANESE}

(37) cak Khuluq lagek ngulang

Mr. Khuluq PROG AV.teach

'Cak Khuluq is teaching.' (15Feb11.087)

(38) naliko pak Suwanan wes mangan, bu Zum lagek budal

when Mr. Suwanan PERF AV.eat Mrs. Zumaroh PROG leave

'When Pak Suwanan had eaten, Bu Zum just left.' (20may11.053)

I discuss the nature of these two different aspectual meanings of lagek with respect to a possible difference in grammatical category in Chapter 2: I suggest lagek as a progressive marker is an auxiliary while lagek as an incentive marker may be an adverb.

\section{1) Lagi Expresses Progressive and Past Progressive}

Aspect marker lagi has description progressive in English Tenses. Progressive aspect can (optionally) be expressed with the auxiliary lagi in Indonesian Javanese (Hengeveld, 2017). Aspect marker lagi may occur before the verb phrase (VP). It can be seen in (6). while in (7) aspect marker lagi before question word for question sentence.

(6) Mboke kita lagi mbasuh gombal kotor Mother-ART DET-my PROG AV-wash chlothes dirty 'My mother is washing dirty clothes.'

(7) Sira lagi apa?

You PROG what

'What are you doing?'

(8) Lagi pada mbaso ning Bu'e PROG meatball in Bu'e '(They) are eating meatball in Bu'e'.
(9) Lagi wingi kita meng Bandung karo bapae kita PAST-PROG yesterday $1 \mathrm{SG}$ go to Bandung with father-ART DET-my

'I was going to Bandung with my father yesterday'

Aspect marker lagi in (8) indicates progressive. Aspect marker lagi in (8) shows that lagi come before verb phrase and lagi as progressive. In Cirebon Javanese aspect marker can be in front of the sentence, so we can tell it a sentence although subject is not in the first sentence. If (8) translated to English, we have to add subject in front of the sentence. Lagi in (9) indicates past progresive. In Cirebon Javanese, there is the different marker to indicate progressive and past progressive in English. Progressive is indicated by is, am, are See (10). While past progressive is indicated by was or were see in (11). Different form Cirebon Javanese that not different marker for progressive and past progressive.

\section{ENGLISH}

(10) She is painting the scanary She PROG V-ING ART scanary

(11) I was buying beautiful dress. I PROG V-ING ADJ dress

\section{2) Lagi cannot be a progressive aspect marker}

I suggest lagek as a progressive marker is an auxiliary while lagek as an inceptive marker may be an adverb (Vander Klok: 2012). Lagek is Paciran Javanse, as lagi in Cirebon Javanese. Aspect marker lagi can not be a progressive aspect marker in some sentences, examples as in (12) and (13) below :

(12) Lagi kaen kita meng umae wa Ahmad ADV that $1 \mathrm{SG}$ to house-ART Uncle Ahmad 'I went to Uncle Ahmad's house that time.'

(13) Lagi bengen mah durung ana mall ning kene kuh ADV past time PART there was not yet mall in here PART

'There was not mall yet here past time.'

For some cases, lagi cannot be a progressive marker. In (12) lagi indicates adverb of time. Tenses for this sentence is past tense although there is aspect marker lagi in front of the sentence. In Cirebon Javanese adverb of time is in the first sentence. It is different from English. In (13) adverb of time is in front of the sentence. Tenses of this sentence is past tense. There are particle in this sentence. Particle is useful for sense of meaning the word or sentence.

\section{Aspect Marker Arep}

The marker arep is used in Indonesian Javanese to mark future tense. The marker arep, mostly considered a volotional and future tense marker in Indonesian Javanese, .... (Hengeveld: 2017). In English to mark future tense using will. The first construction to be found in Foundations is labeled as the future non-progressive. It is described as the modal verbs will/shall 
followed by the plain infinitive and it covers especially neutral predictions without attitudinal implications.

\section{1) Arep Expresses Future}

The marker arep (14) expresses future and can occur with verb phrase predicates (e.g. mene 'come here'). In Cirebon javanese there is not difference aspect marker arep as future tense between verb phrase predicate (14) and adjective phrase predicate (15) (e.g. happy). it is different from English that aspect marker will for verb phrase predicate and aspect marker will be for adjective phrase predicate.

\section{CIREBON JAVANESE}

(14) Friza arep teka mene jehsukiki Friza FUT come here PAR tomorrow 'Friza will come here tomorrow'.

(15) Nok Lia arep seneng ora sida gara-gara omongane bature

Nok Lia FUT happy not done because of talkingART friend-ART

'Nok Lia will be happy but it will not be done because of her friend talking'.

\section{2) The distinguish arep with will and be going to}

\section{ENGLISH}

(16) I have been ready, I am going to go to Jakarta

(17) I will go to Jakarta tomorrow

\section{CIREBON JAVANESE}

(18) Ayu temen sira kuh, arep miang mendi sih? Beautiful very you PART going to go where PART

'You are very beautiful, where are (you) going to go?

(19) Mamange kita arep pindah meng Bandung Uncle-ART ART will move to Bandung 'My uncle will move to Bandung.'

Future aspect marker in English has different aspect markers. Will to appear planing (it can't be sure yet), this planing can be change because of the time distance see (17). While (18) aspect to be going to appears the situation or the activity can be sure done, it can be changed. Different from English, Cirebon Javanese aspect marker arep used for all situations, the situation is sure done (19) or situation is not sure done (18).

\section{3) Arep may also expresses wish CIREBON JAVANESE}

(20) Sira diarep arep senget wingi, ora teka-teka You wish from yesterday didn't come
(I) Wished you come here yesterday, (but) (you) didn't come

Arep may also expresses wish when it is repeated. It can be seen in (20) arep can be wish in past.

Basically, Cirebon Javanese and Javanese in other dialect has the same pattern for tenses. Tenses, aspect marker and modality of Javanese dialect Paciran has been researched by Vander Klok (2012). Pattern of tenses between Cirebon Javanese and Paciran Javanese are same, but Vander Klok (2012) research does not tell about Arep or Ape (in Paciran Javanese dialect) expresses wish.

\section{CONCLUSION}

Actually Cirebon Javanese is not a different pattern from other Javanese dialects. Cirebon Javanese has different vocabulary from other dialects Javanese, but for aspect markers, Cirebon Javanese's aspect markers are the same as standard Javanese's aspect markers.

\section{REFERENCES}

Cole, P., Hara, Y., \& Yap, N. T. H. (2008). Auxiliary fronting in Peranakan Javanese. Linguistics, 44 (1), 1-43. doi: 10.1017/s002222670700494x

Comrie, B. (1976). The syntax of causative construction: cross-language similarities and divergences. In M. Shibatani (ed.), Syntax and semantics 6, (pp. 261-312). New York: Academic Press.

Conners, T. (2008). Tengger Javanese. Unpublished, doctoral dissertation, Yale University, New Haven, USA.

Dahl, Ö. (1985). Tense and aspect systems. New York: Blackwell.

Ewing, M. (2005). Grammar and inference in conversation: Identifying clause structure in spoken Javanese. Philadelphia: John Benjamins.

Ewing, M. (2014). Two pathways to identifiability in Cirebon Javanese. Santa Barbara: University of California at Santa Barbara.

Favre, L. (1866). Grammaire javanaise Paris: L'imprimerie Impériale.

Goebel, Z. (2002). Code choice in interetchnic interactions in two urban neighborhoods of Central Java Indonesia. International Journal of The Sociology of Language, 2002(158), 69-87. doi: 10.1515/ijsl.2002.052

Goebel, Z. (2005). An ethnographic study of code choice in two neighboarhood of Indonesia. Australian Journal of Linguistics, 25(1), 85-107. doi: $10.1080 / 07268600500113674$

Goebel, Z. (2010). Language, migration and identity in Indonesian: The case of Sudah, Telah, Pernah, Sempat. Wacana, 12(2), 243-268. doi: 10.17510/wjhi.v12i2.117

Hoogervorst, T. G. (2010). Describing Surabaya's linguistic ecology (Unpublished master's thesis). Leiden University.

Horne, E. C. (1961). Begining Javanese Vol. 3 Yale Linguistic Series. New Heaven: Yale University Press.

Robson, S. (1992). Javanese grammar for students. Glen Waverley: Monash Papers on Southeast Asia.

Robson, S. \& Wibisono, S. (2002). Javanese English dictionary. North Claredon: Tuttle Publishing.

Suwadji. (1981). Struktur dialek bahasa Jawa di Pesisir Utara Jawa Tengah. Jakarta: Departemen Pendidikan dan Kebudayaan, Pusat Pembinaan dan Pengembangan Bahasa.

Uhlenbeck, E. M. (1975). Sentence segment and word group: Basic concepts of Javanese syntax. In Nusa (ed. J.W.M. Verhaar, 6 - 10 Jakarta: Nusa

Vander Klok, J. (2012). Tense, aspect, and modal markers in Paciran Javanese Department of Linguistics. Honours B.A., Etudes Françaises, York University.

Vander Klok, J. (2015). Distinguishing already from perfect aspect: A case study of Javanese wis. Ocenic Linguistic, 54(1), 172-205. doi: 10.1353/ol.2015.000 